\title{
Using Setswana in business transactions in the clothing industry at the West Rand District Municipality in Gauteng
}

\begin{tabular}{|c|c|}
\hline \multicolumn{2}{|c|}{$\begin{array}{l}\text { Authors: } \\
\text { Solomon T. Macucwa }{ }^{1} \text { (1) } \\
\text { Thabo Ditsele }^{1} \text { (D) } \\
\text { Mary M. Makgato }^{1} \text { (1) }\end{array}$} \\
\hline \multicolumn{2}{|c|}{$\begin{array}{l}\text { Affiliations: } \\
\text { 'Department of Applied } \\
\text { Languages, Faculty of } \\
\text { Humanities, Tshwane } \\
\text { University of Technology, } \\
\text { Pretoria, South Africa }\end{array}$} \\
\hline \multicolumn{2}{|c|}{$\begin{array}{l}\text { Corresponding author: } \\
\text { Thabo Ditsele, } \\
\text { ditsele@hotmail.com }\end{array}$} \\
\hline \multicolumn{2}{|c|}{$\begin{array}{l}\text { Dates: } \\
\text { Received: } 22 \text { Mar. } 2020 \\
\text { Accepted: } 06 \text { Aug. } 2020 \\
\text { Published: } 24 \text { Nov. } 2020\end{array}$} \\
\hline \multicolumn{2}{|c|}{$\begin{array}{l}\text { How to cite this article: } \\
\text { Macucwa, S.T., Ditsele, T. \& } \\
\text { Makgato, M.M., 2020, 'Using } \\
\text { Setswana in business } \\
\text { transactions in the clothing } \\
\text { industry at the West Rand } \\
\text { District Municipality in } \\
\text { Gauteng', The Journal for } \\
\text { Transdisciplinary Research in } \\
\text { Southern Africa 16(1), a856. } \\
\text { https://doi.org/10.4102/ } \\
\text { td.v16i1.856 }\end{array}$} \\
\hline \multicolumn{2}{|c|}{$\begin{array}{l}\text { Copyright: } \\
\text { (c) 2020. The Authors } \\
\text { Licensee: AOSIS. This } \\
\text { is licensed under the } \\
\text { Creative Commons } \\
\text { Attribution License. }\end{array}$} \\
\hline \multicolumn{2}{|l|}{ Read online: } \\
\hline 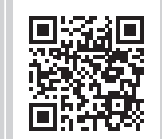 & $\begin{array}{l}\text { Scan this } Q R \\
\text { code with your } \\
\text { smart phone or } \\
\text { mobile device } \\
\text { to read online. }\end{array}$ \\
\hline
\end{tabular}

According to Census 2011, the three languages with the highest number of first language (L1) speakers in the West Rand District Municipality in Gauteng are Setswana (27.3\%), Afrikaans $(16.9 \%)$ and isiXhosa (14.9\%). This district municipality comprises the following three local municipalities: Mogale City (including Krugersdorp); Rand West City (including Randfontein) and Merafong City (including Carletonville). Setswana has more L1 speakers in two out of the three local municipalities, namely Mogale City (31.7\%) and Rand West City (24.3\%). In Merafong City, Setswana has the second highest percentage of L1 speakers at $21.4 \%$, the highest being isiXhosa at $24.9 \%$. While this district municipality does not have a majority language, Setswana is the most spoken among its black residents. The objective of this article was to analyse how Setswana is used in business interactions at clothing stores in the West Rand District Municipality. A qualitative approach (through interviews and participant observation) was used to gather data at clothing stores in Krugersdorp, Randfontein and Carletonville. Customers preferred to be addressed in Setswana by salespersons at clothing stores, but they conceded that the language lacks adequate terminologies to be used effectively in this industry.

Keywords: Setswana; business language; communication patterns; district municipality; Gauteng; South Africa.

\section{Introduction}

Language has an important connection to an individual's cultural heritage and society (MacMillan 1998:17). In order for a language to survive or not become extinct, the key solution lies in its usage. The use of black South African languages (BSALs), such as Setswana, in the socio-economic sector is of great significance in areas where such languages have a majority or a significant number of L1 speakers. Anecdotal evidence suggests that in South Africa, business transactions are conducted in English, even when customers and salespersons speak a common BSAL. One such case study is in Gauteng's West Rand District Municipality where Setswana has more L1 speakers than other languages, including English, where business transactions are not conducted in Setswana, but in English.

\section{Phaahla (2006a) asserts that:}

Since the democratic elections of 1994 in South Africa, people have been grappling with the issue among others, of the financial costs of using more than one official language in commerce and industry, but without giving due weight to the fact that South Africa is a multilingual country expect to say that using several official languages in parallel would be contingent on practicality and expense. (p. 142)

Regarding the use of BSALs, Ditsele (2016:1, 2017:15) contends that when it comes to formal domains (e.g. education, media, government and business), they are not as developed as English and Afrikaans. De Klerk (1999:312) remarks that many L1 speakers of BSALs regard them as worthless, because of their functional limitations, with regard to access to participation and mobility in wider society. Alexander (2000:10) maintains that except if the authorisation of language rights include the use of BSALs in all informal and formal functions, the empowerment of black South Africans will remain ineffective.

\section{Phaahla (2006a) posits that:}

In view of the unprecedented globalisation wave sweeping the world today, the sophistication of Black languages should be significantly stepped up from their normal range of mundane discourse to an economic discourse so that mother-tongue speakers can take charge of their languages and compete locally in terms of being generally innovative and competent in the domain of business, assuming that a 
new-found confidence will expand their language use and make knowledge readily accessible for trade and business purposes. (p. 145)

\section{Hypotheses}

This article sought to prove or disprove the following three hypotheses regarding communication patterns and interactions between Setswana-speaking consumers and salespersons at clothing stores in the West Rand District Municipality:

- The choice to speak (or not to speak) Setswana during business transactions is determined by clothing stores (salespersons) and not by their customers (i.e. consumers of goods).

- The choice to speak (or not to speak) Setswana by clothing stores (salespersons) during business transactions does not influence customers' decision to return to such clothing stores.

- Setswana is moderately used in the clothing industry and is inadequately developed for business transactions in this industry.

\section{Literature review}

\section{Setswana}

Setswana, also known as 'Tswana' or more archaically 'Chuana' or 'Sechuana', is a Bantu language spoken by an estimated 4 million people in South Africa (Bennett et al. 2016:235). Ditsele (2016:2) posits that Setswana is one of the 11 official languages of South Africa and one of the two official languages spoken in Botswana. According to Section 6 of the new and/or amended constitution of Zimbabwe (Act 20 of 2013), Setswana is now also one of the official languages in Zimbabwe.

Cole (1992:xv) states that Setswana is the most widely spread Bantu language in Southern Africa. He furthermore highlights that it is spoken by the predominant tribes of the Bechuanaland Protectorate (now known as Botswana), northeastern Cape (now the Northern Cape Province of South Africa), central and western Free State, and western Transvaal (now part of the South African provinces of North West and Gauteng). Ranamane (2012:27) concurs with Cole's views that Setswana is mainly spoken in the North West Province of South Africa, in the northern region of the Northern Cape Province, as well as the central and southern parts of the Free State Province, particularly in Thaba Nchu.

Ditsele (2016:2) notes that in Gauteng Province, Setswana is more concentrated in the western and north-western areas of the province. He elaborates further that Setswana has more speakers than other languages in the two local municipalities of the West Rand District Municipality, namely Mogale City and Rand West City, and it is a significant language in the City of Tshwane Metropolitan Municipality (ÁlvarezMosquera, Bornman \& Ditsele 2018:442; Wagner, Ditsele \& Makgato 2020:2), where it has the third highest percentage of speakers after Afrikaans and Northern Sotho.
According to Census 2011, the West Rand District Municipality is multilingual and does not have a L1 that is in the majority. Setswana has the highest percentage of L1 speakers $(27.3 \%)$ and is the most spoken language in this municipality. Setswana has a majority of L1 speakers in black townships, for example, Munsieville has $67.2 \%$ in Mogale City, and Mohlakeng has 55\% in Randfontein. The language has more L1 speakers than other languages in Kagiso (47.6\%) in Mogale City and Khutsong (34.8\%) in Merafong City.

\section{Communication}

In order for business interactions to occur, there has to be human communication involved. Magocha (2010:1) asserts that good communication is extremely important and necessary for business as is the need for organisations to increase their profits. Grin (1994:34) admits that people who want to do business with one another need to be able to communicate on an appropriate level of competence in the same language. Cleary (2014:1) defines 'communication as the process of creating meaning between two or more people through the expression and interpretation of messages'. Erasmus-Kritzinger, Bowler and Goliath (2009:3) concur with Cleary (2014) that:

$[C]$ ommunication can be defined as a two-way process whereby information (the message) is sent from one person (the sender) through a channel to another (the receiver) who in turn reacts by providing feedback. (p. 1)

Neuliep (2006:9) submits that communication has enormous effect on human beings. People conduct their lives through communication. Communication is the method by which people initiate, maintain and terminate their relationships with others. Human beings influence and persuade each other through the use of communication. Neuliep (2006:29) asserts that 'successfully interacting with someone from a different culture requires a degree of communication competence'.

\section{Language practice and economics}

The people of South Africa show interest and commitment towards the use of their languages in contrast to major institutional structures and processes, for example, there is a significant number of listeners of radio stations broadcasting in BSALs, compared to the use of BSALs by politicians, at schools or in the print media (Phaahla 2015:181). Alexander (2000:10) notes the extent to which the usage of 'language rights' of BSALs should be applied in all language domains.

South African language practices promote monolingualism in English compared to its language policy which promotes multilingualism, which is what linguists refer to as the 'diffusion-of-English paradigm' (Phaahla 2015). She furthermore posits that:

With regards to the language practices in business, education, the media and other domains of higher functions, it remains true that in South Africa the 'diffusion-of-English paradigm' is gaining momentum in virtually all the country's institutions. (p. 181) 
Phaahla (2015:181) posits that there is a marked contrast between South Africa's multilingual language policy and its language practices and behaviour. Phaahla (2006a) contends that:

[W] hat really happened after 1994 is that most higher education institutions, parastatals, statutory bodies and some industries, irrespective of what their language policies prescribe, have shifted from bilingualism towards monolingualism. (p. 142)

Furthermore, Phaahla (2015:182) postulates that the significance of assessing the implications of implementing new language policy options for business in South Africa lies in observing 'international trends' in language policy and their relation to political ideology and free-enterprise economics.

According to Phaahla (2006b:57), black South Africans assume that it is impossible to do business in other languages besides English. Phaahla (2006b) submits that:

South Africans knowledge of English, especially in the lower socio-economic strata, does not equip them adequately to function and perform optimally in commerce and industry, or to participate effectively in economic activity. (p. 195)

Various sectors maintain the status quo of using English, whereas their growth depends on the speakers of BSALs (e.g. financial institutions). Black South African languages are neglected, given the reason that they lack terminology and funding (Phaahla, 2006a:147). Phaahla (2010:56) posits that 'it would seem economically sensible for banks and other financial institutions to implement multilingualism in their everyday activities and accommodate regional languages'.

According to Heugh (2000:467), BSALs can be useful if the stigma of colonised consciousness does not exist and until their potential in economic activities is revealed. PanSALB (2000:73) commissioned MarkData which found that the extent to which the languages are accommodated in the bureaucracy, civil society and the economy has only an approximate relationship to the degree of concern about language policy. To promote multilingualism in South Africa, the Use of Official Languages Act (No. 12 of 2012) was introduced to promote the use of BSALs at national government level and parastatals (Republic of South Africa 2012). This Act makes provision for a minimum of three languages to be used in domains of higher functions. Phaahla (2015:182) refers to this occurrence as a bold stance taken by the South African government, but it remains to be seen if the government's intention will change the attitudes, language practice and behaviour of bureaucrats and L1 speakers of BSALs. Mohlahlo (2019) found that bureaucrats at national departments, many of them being speakers of BSALs, were reluctant to implement this Act and viewed multilingualism as a problem and not a strength. They held a view that the status quo of English dominance should be maintained. These negative attitudes held towards the use of BSALs at national government effectively sabotage the Act in particular and the Constitution of South Africa (Republic of South Africa 1996) in general.

\section{Research approach}

This study adopted a qualitative research approach which Creswell (2014:5) conceptualises as an approach for exploring and understanding the meaning individuals or groups ascribed to a social or human problem. Creswell (2014) further notes that the process of research involves emerging questions and procedures, data typically collected in the participant's setting, data analysis inductively building from particulars to general themes and the researcher making interpretations of the meaning of the data. Primarily, this is an exploratory study which allowed researchers to acquire an understanding of underlying reasons, opinions and motivations as it envisages to provide insights and uncover trends in thoughts and opinions while diving deeper into the problem.

Data were gathered using semi-structured interview questions. Semi-structured interviews rely on the interviewer following up with probes to get in-depth information on topics of interest. More data were gathered through participant observation, which is a qualitative method with roots in traditional ethnographic research, whose objective is to help researchers learn the perspectives held by the study populations. As qualitative researchers, people presume that there will be multiple perspectives within any given community. They are interested both in knowing what those diverse perspectives are and in understanding the interplay among them (Mack et al. 2005:13).

\section{Ethical consideration}

Before the commencement of data collection, ethical clearance was obtained from Tshwane University of Technology, Faculty Committee for Research Ethics - Humanities [FCREHUM] on 13 June 2017, with ethical clearance number FCRE/ APL/STD/2017/0. Permission to conduct research at research sites (i.e. clothing stores) was granted by each research sites' management.

\section{Research sites and participants}

Data were gathered at nine clothing stores in Krugersdorp, Randfontein and Carletonville (all in the West Rand District Municipality), that is, three clothing stores from each town. The three clothing stores were selected because each of them had price ranges which targeted and/or appealed low-, middle- and high-income earners. For the purposes of this study, these clothing stores' price ranges were used to categorise customers for convenience, and thus, the social class categories were perceived, that is, they were not scientific.

Participants were residents of the West Rand District Municipality who ordinarily communicated in Setswana (viz. L1 and L2 speakers). The sample population consisted of 36 participants, that is, 18 customers (two from each of the nine clothing stores) and 18 salespersons (two from each of the nine clothing stores). 
For customers, the following five variables were used: (1) sex, (2) age group, (3) competence in Setswana, (4) level of education and (5) residence. For salespersons, the following five variables were used: (1) sex, (2) age group, (3) competence in Setswana, (4) duration at the workplace and (5) location of the clothing store. As shown in Appendix 1 (Customers' biographic profiles) and Appendix 2 (Salespersons' biographic profiles), codes were generated to protect the identities of all 36 participants.

The first author placed himself in the 'enquiries section' of the clothing stores; this is a section where customers make enquiries about their accounts and return and/or exchange items they bought. This section was ideal for the first author to observe conversations between customers and salespersons.

Before customers interacted with salespersons (clothing store staff members), the first author established the language repertoire of the salespersons, so as to identify those who ordinarily speak Setswana (i.e. L1 or L2 speakers); these were salespersons that he paid attention to when they assisted customers. In an event, a conversation took place in Setswana, however minimal that was, the first author approached the customer after the conclusion of the business transaction (conversation with the seller) to request permission to interview them at a discreet location pre-authorised by management at each clothing store.

After interviewing the adequate number of customers, the first author then interviewed salespersons. The reason for interviewing salespersons at the end of the process was to ensure that they did not change their linguistic behaviour while interacting with customers, as that would have defeated the purpose of this study.

\section{Findings and discussions Analysis of customers' data}

The following questions were posed to the 18 customers through face-to-face interviews.

Question 1: When you approach a black staff member at this clothing store and suspect that s/he could speak Setswana, do you start the conversation in Setswana?

All the customers stated that they started conversations in Setswana. The most common reason they gave was that there was an assumption that most black people in the West Rand District Municipality speak Setswana, as it is the most dominant language. CM3-CS1 noted that while he started conversations in Setswana, he usually carried on with the language a staff member would respond in.

Question 2: If a staff member at this clothing store responds to you in Setswana, but then switches to another language which you understand, do you change as well or do you continue to speak to him/ her in Setswana?

Many customers said that they switched to another language to accommodate a staff member in the conversation and establish rapport with them. Six customers (viz. CM1-CS2, CF4-CS3, CM5-CS3, CF7-CS3, CF10-CS3 and CF11-CS3) admitted that they were comfortable speaking Setswana, thus did not switch to another language because by initially speaking Setswana, a staff member would have indicated that they understood the language.

Question 3: If you overhear a staff member at this clothing store speak Setswana to his/her colleague, but starts a conversation with you in another language, do you continue to speak Setswana to him/her or do you speak the language that s/he speaks if you understand it?

Some customers reported that they preferred to communicate in Setswana than in another language. One such customer was CF11-CS3, who pointed out that some staff members had a bad attitude and treated customers badly compared to their colleagues, hence their negative attitudes towards communicating with customers in Setswana. Other customers said that they would switch to the language preferred by the staff member, only if they could communicate in that language. CF8-CS1 and CF9-CS2 said that switching to a language to a language a staff member approached them in has the potential to build some rapport between them and staff members.

Question 4: How do you feel about a staff member whom you just overheard speaking Setswana to his/her colleagues, but refuses to speak to you in this language?

Many customers said that such behaviour would make them feel unwelcomed as it would be a display of a bad attitude. CF7-CS3 went further by saying that refusing to communicate in Setswana would send a message that a staff member did not appreciate BSALs, while CM7-CS2 and CF11-CS3 said that when a staff member refused to speak Setswana with them, they would not take that they would feel discriminated against.

A few customers said that it would not matter to them if a staff member refused to speak to them in Setswana. CF3-CS2 and CM2-CS3, CF8-CS1 and CF10-CS3 said that what was important to them was being on the same page with a staff member, while CM3-CS1 responded that if such a staff member communicated with him in English, he would understand that a staff member would be trying to be professional.

Question 5: If you hear from people that workers of other clothing stores selling similar items as this store in this town prefer to speak to customers in Setswana, does this influence you to visit that clothing store and possibly buy from it?

Many customers stated that it would influence them to visit and buy at other clothing stores because such an attitude would give them an impression that such stores would be interested in ensuring that customers fully understood transactions and that they would be promoting the use of BSALs.

A few customers said that the choice of language would not influence them to visit other clothing stores. CF1-CS1 and 
CM2-CS3 stated that they would only visit other clothing stores for price comparison, while CM3-CS1 said that he would visit other clothing stores should he hear that they had reduces their prices. CF9-CS2 and CF11-CS3 said they would be influenced by better treatment of customers rather than the choice of a language, even if it was Setswana. The latter pointed out that a staff member could still display a bad attitude towards customers while communicating with them in Setswana.

Question 6: Based on your observation while you are in this clothing store and listening to interactions between customers and staff members who are both black, how would you rate the frequency of Setswana spoken by them - very little, enough or most of the time?

Many customers suggested that very little Setswana was spoken, and CM1-CS2, CM2-CS3 and CF4-CS3 added that English was spoken more frequently. Two customers (viz. CM3-CS1 and CF6-CS2) said that enough Setswana was spoken, while another two (viz. CF1-CS1 and CF2-CS1) stated that Setswana was spoken most of the time during interactions between staff members and customers. CF3CS2 said that she had not made any observations because she did not eavesdrop on other people's conversations.

Question 7: Do you think that Setswana is developed enough to allow you to speak it at all times when buying items from this clothing store?

Many customers stated that Setswana was developed enough because they could use the language to purchase items at the clothing stores. A few of them disagreed that Setswana was developed enough; CF9-CS2 said that the language was developed enough for other communication purposes, but not in the business domain because it fell short on business jargon. CF7-CS3 agreed with this view about Setswana's lack of terminology and relied on borrowing words, for example: hempe (Afrikaans: 'hemp'), dibutshu (English: 'boots'), diteki (Afrikaans: 'tekkies') or dipump (English: 'pumps'). CF2-CS1 and CF6-CS2 suggested that Setswana was not developed enough because its L1 speakers communicated in English when buying items in the clothing stores.

Question 8: When you bought items at this clothing store - be it today or in the past - and spoke Setswana, have you ever switched to another language because you struggled with Setswana words that would have allowed you to explain yourself clearly?

Many customers said that they had switched to another language, one of them being CM1-CS2, who said that he did so when he inquired about sizes, such as that of a pair of trousers. CF5-CS1 responded that she switched to another language when she had to use words which she did not readily know their Setswana equivalents, such as 'sale', 'promotion', 'eyeliner' or 'eyebrow pencil', and CF8-CS1 said that she did not know Setswana's equivalence of 'hairpiece', so she switched.

A few customers said that they did not switch, one of them being CF3-CS2, who said that she had not switched because she did not struggle with Setswana words and could explain herself well in the language.

\section{Analysis of salespersons' data}

The following questions were posed to the 18 salespersons through face-to-face interviews.

Question 1: When you are approached by a black customer and suspect that s/he could speak Setswana, do you start the conversation in Setswana?

A majority of salespersons said that they started conversations in English because it was a business language. SF1-CS1, SM2CS2, SF8-CS2 and SF11-CS3 submitted that management required them to address customers in English and only switch to another language, if customers were comfortable speaking an alternative language to English. SF2-CS2 and SM5-CS2 said that they started conversations in English because they could not tell upfront whether customers were Setswana speakers. A few salespersons (viz. SM1-CS1, SM4CS3 and SF3-CS1) stated that they started conversations in Setswana because a majority of black customers in their towns spoke Setswana.

Question 2: If a customer responds to you in Setswana, but then switches to another language which you understand, do you change as well or do you continue to speak to him/her in Setswana?

All salespersons said that they changed in order to accommodate customers and to develop rapport with them through allowing conversations to flow. SF8-CS2 mentioned that the cell phones department did not allow for purchased items to be returned; hence, she changed the language in order for her and the customers to understand each other very well. SF3-CS1 said that she continued to speak Setswana because she was more comfortable speaking the language.

Question 3: If you hear a customer speak Setswana to his/her companion, but starts a conversation with you in another language, do you continue to speak Setswana to him/her or do you speak the language that s/he speaks if you understand it?

The majority of the salespersons stated that they spoke a language that a customer approached them in because it gave the impression that a customer was comfortable engaging with, in that language, and it demonstrated the customer's language preference. A few of them (viz. SF5-CS3 and SF10-CS3) said that they continued to speak Setswana; SM3-CS3 said that he did so Setswana to avoid communication barriers.

Question 4: If you hear from customers that staff members at other clothing stores which compete with yours in this town prefer to speak to customers in Setswana, does this influence you to speak to your customers in Setswana in order not to lose them to your competition?

Many salespersons stated that hearing from customers that staff members at clothing stores in competition with theirs preferred to speak to customers in Setswana would influence 
them to speak Setswana to their customers because of the fact that it was their priority to cater for their customers' needs, and it would be an act of offering a good customer service.

A few of them said that it would not influence them to speak Setswana to their customers, but would stick to English as it was a business language. SM1-CS1 mentioned that it did not matter which language a salesperson spoke, what was important was that the communication should be successful. SF4-CS1 said 'No, I do not believe that we can lose customers due to not speaking Setswana. Customers know that our store serves customers who speak different languages'. SF5CS3 answered that customers who came to their store were interested in the style and quality of items available, not the choice of language used.

Question 5: Based on your observation of conversations between your black colleagues and black customers, how would you rate the frequency of Setswana spoken by them - very little, enough or most of the time?

Some salespersons (viz. SM3-CS3 and SM4-CS3) reported that very little Setswana was spoken because many black customers were not comfortable with speaking BSALs and instead preferred to communicate in English more often. SF9CS2 answered that very little Setswana was spoken because English was the language used in business transactions. Other salespersons (viz. SM1-CS1 and SF1-CS1) stated that there was enough Setswana spoken between salespersons and customers. Others (SF2-CS2 and SM2-CS2) suggested that Setswana was spoken most of the time.

Question 6: Do you think that Setswana is developed enough to allow you to speak it at all times when interacting with black customers?

Some salespersons (e.g. SF4-CS1) thought that Setswana was developed enough to speak it all the time; SF3-CS1 said that even white people in Randfontein could speak it during interactions in the store. Others felt that the language was not developed enough to speak it all the time and that English was better suited to conduct business transactions at clothing stores; SM4-CS3 were of the view that Setswana lacked business jargon, for example, he did not know the language's equivalent of 'merchandise'.

Question 7: When you interact with customers - be it today or in the past - and spoke Setswana with them, have you ever switched to another language because you struggled with Setswana words that would have allowed you to explain yourself clearly?

The majority of the salespersons said that they switched to English because they were used to communicating in Setswana at their workplaces. SM5-CS2 said that he struggled to sustain lengthy conversations in Setswana because it was his L2. SF5-CS3 indicated that she switched because of a lack of Setswana terminology for words such as 'account' and 'insurance', a view which was also expressed by SF8-CS2, who pointed out that she did not know Setswana equivalents for words like 'memory', 'mega bytes' and 'data'. A few salespersons (e.g. SM1-CS1 and SF1-CS1) that they had had not switched to another language because they were comfortable with expressing themselves well in Setswana.
Question 8: Do you think that Setswana and other BSALs should be spoken at all when engaging in a conversation with customers?

All the salespersons agreed that BSALs should be spoken with customers because they had official status in South Africa and that stores would be accommodating different customers by allowing these languages to be spoken. In addition, speaking them at all times would also contribute to their further development.

\section{The influence of variables on customers}

As indicated earlier, data were gathered using the following five variables: (1) sex, (2) age group, (3) competence in Setswana, (4) level of education and (5) residence. The analysis below incorporates the authors' notes from interactions with all participants.

A variable 'sex' was not a factor in influencing the opinions of customers with regard to communicating in Setswana in business interactions because both female and male customers offered similar answers.

The youngest 'age group' (i.e. 18-29 years) did not hold strong feelings towards the use of Setswana in clothing stores; in other words, it was not an issue for them whether Setswana was spoken and would not insist on the language being spoken to them. The 'age group' in the middle (i.e. 30-49 years) did not think that Setswana was adequately developed for communication in business transactions. Be that as it may, they stated that if staff members at clothing stores spoke Setswana more often, that would influence them to visit such stores and buy from them. The oldest 'age group' (i.e. 50-59 years) held strong feelings towards salespersons who did not want to interact in Setswana with customers. They also noted that it would influence them to visit and possibly buy from stores whose staff members communicated more often in Setswana with customers. A finding is thus made that the older the participants were, the more they felt attached to Setswana and supported the idea of the language being used between customers and clothing stores' staff members.

Variables 'Competence in Setswana' and 'residence' were intertwined because eight participants who were Setswana L1 speakers resided in Krugersdorp and Randfontein (and none in Carletonville), while 10 of those who were Setswana L2 speakers resided mainly in Carletonville (6), and a few in Krugersdorp (2) and Randfontein (2). On the one hand, the eight Setswana L1 speakers stated that they would be influenced to visit clothing stores whose staff members preferred to interact with customers more often in Setswana. They also would not feel welcomed in clothing stores whose staff members refused to communicate with customers in Setswana. On the other hand, the 10 Setswana L2 speakers said that they were not influenced by the use of Setswana (or lack thereof) at clothing stores; instead, what would influence them in visiting other clothing stores would be the price of items, customer service and fashion style offered there. Also, 
they were not bothered by staff members' attitudes of refusing to communicate with customers in Setswana during business interactions.

Setswana L1 speakers and residents of Krugersdorp and Randfontein showed emotional attachment to the language, compared to L2 speakers and residents of Carletonville. A conclusion is thus made that 'competence in Setswana' and 'residence' were factors in influencing customers on the use of Setswana in business transactions in the clothing industry.

When it comes to 'level of education', participants who did not hold a Grade 12 Certificate felt strongly that Setswana should be used for communication between customers and clothing stores' staff members. They preferred that communication be held in Setswana if given the chance and space by staff members, but usually did not initiate conversations in Setswana. Participants who held a Grade 12 and National Diploma Certificates, were more interested in the success of their business interactions, irrespective of the language choice. They also spoke little or no Setswana when involved in business interactions and had no issue with communicating wholly or partly in English. According to Peters and Brijal (2011:272), education is a prerequisite for having a skill of communicating effectively.

A conclusion is thus reached that the lower the participants' level of education, the more they wanted to communicate in Setswana, and by default, not in English. The language of teaching and learning which many black South Africans access education through is English. This means that one's level of education translates into more access to English. This possibly explains why participants who held a Grade 12 Certificate and above were more open to communicating in English, as opposed to Setswana.

\section{The influence of variables on salespersons}

As indicated earlier, data were gathered using the following five variables: (1) sex, (2) age group, (3) competence in Setswana, (4) duration at the workplace and (5) location of the clothing store. The analysis below incorporates the authors' notes from interactions with all participants.

Variables 'sex', 'age group' and 'duration at the workplace' were not factors in influencing the opinions of salespersons when it came to communicating in Setswana in business interactions in the clothing industry, as those who belonged to the same categories in these variables offered similar answers.

Compared to salespersons who were Setswana L2 speakers, those who were L1 speakers indicated that they spoke Setswana a lot more with customers who were comfortable in communication in the language during business interactions. As such, 'competence in Setswana' was a factor in influencing salespersons' views on the use of Setswana in the clothing industry.
With regard to 'location of the clothing store', this did not entirely determine which language salespersons chose to communicate with customers, rather it influenced which language salespersons spoke to customers in addition to Setswana. For instance, in Carletonville and Randfontein, they spoke isiXhosa, while in Krugersdorp they spoke isiZulu. That was because of the fact that isiXhosa was a significant language at Merafong Local Municipality (which includes Carletonville) and at Rand West City Local Municipality (which includes Randfontein), while isiZulu was a significant language at Mogale City Local Municipality (which includes Krugersdorp). This means that 'location of the clothing store' was a factor in influencing alternative BSALs which salespersons opted for.

\section{Participant observation}

Before engaging with customers and salespersons, the first author visited the clothing stores and observed (from a reasonable distance) interactions between the two stakeholders so that by the time he interviewed them, he would have a better understanding of how they interact. These are some of his observations:

- Customers used words that products were advertised in when they struggled with Setswana equivalents.

- Customers in Krugersdorp and Randfontein approached salespersons in Setswana a lot more than those in Carletonville.

- English was the default language which salespersons used to attend to customers standing in queues, such as 'Next customer please'. It was used even when all were black customers.

- At a 'new accounts department', a black customer who struggled in English left the store without opening a new account because assistance was only offered in that language and not in Setswana.

- In a majority of cases, salespersons determined the choice of language used between themselves and customers.

- English was the most preferred language by customers and salespersons at CS3 (viz. clothing stores catering for high-income earners).

- Customers who shopped at CS3 stores valued good service regardless of the choice of language it was delivered in.

- In most cases, elderly customers whose L1 was Setswana demanded to be assisted in the language only when they experienced difficultly in communicating in other languages.

\section{Conclusion}

At the beginning of this article, the authors stated that they sought to prove or disprove three hypotheses regarding communication patterns and interactions between Setswanaspeaking consumers and salespersons at clothing stores in the West Rand District Municipality.

With reference to the first hypothesis, the choice to speak (or not to speak) Setswana during business transactions was 
determined by both customers and salespersons. The decision to choose a particular language or shift to another was determined by either party (i.e. customers or salespersons), and it was largely informed by ensuring that there was no misunderstanding between the two parties. Therefore, it is concluded that the hypothesis has been proven to be false.

In terms of the second hypothesis, customers indicated that their choices to return to clothing stores were influenced by factors such as the quality of customer service, competitive prices and fashion sense, and not by the choice of language initiated by them or salespersons. Therefore, it is concluded that the hypothesis has been proven to be true.

Looking at the third hypothesis, customers and salespersons said that they communicated in Setswana to build rapport between themselves, although they switched to English where Setswana lacked terminologies. Further evidence suggested that they used Setswana moderately and they believed that the language was inadequately developed for use in conducting business transactions in the clothing industry. Therefore, it is concluded that the hypothesis has been proven to be true.

In his comprehensive study on 'attitudes towards Setswana by its L1 speakers', Ditsele (2014:268) argues that society would develop positive attitudes towards the use of Setswana beyond informal settings only if certified knowledge of it is translated into economic benefits. In line with Ditsele's argument, this article revealed that customers, particularly Setswana L1 speakers, found it valuable to communicate in their L1 when engaging in business interactions at clothing stores, which are formal settings. Tapping into the relationship between 'language' and 'economics' which Phaahla (2015:181) alludes to, this study has added new knowledge to this area of research in South Africa.

\section{Acknowledgements}

We wish to express our sincere appreciation to the customers and salespersons at clothing stores in Krugersdorp, Randfontein and Carletonville.

\section{Competing interests}

The authors have declared that no competing interest exists.

\section{Authors' contributions}

S.T.M. was a Master's student and developed the article from his dissertation. T.D. was S.T.M.'s main supervisor, and he re-worked the first draft. M.M.M. was S.T.M.'s co-supervisor and reviewed the re-worked draft, which was finalised by T.D. The contribution to the article is as follows: S.T.M. (30\%), T.D. $(60 \%)$ and M.M.M. (10\%).

\section{Funding information}

This research received no specific grant from any funding agency in the public, commercial or not-for-profit sectors.

\section{Data availability statement}

Data sharing is not applicable to this article as no new data were created or analysed in the study.

\section{Disclaimer}

The views and opinions expressed in this article are those of the authors and do not necessarily reflect the official policy or position of any affiliated agency or the authors.

\section{References}

Alexander, N., 2000, Language policy and planning in South Africa: Some insights, Buchu Books, Cape Town.

Álvarez-Mosquera, P., Bornman, E. \& Ditsele, T., 2018, 'Residents' perceptions on Sepitori, a mixed language spoken in greater Pretoria, Tshwane', Sociolinguistic Studies 12(3-4), 439-459. https://doi.org/10.1558/sols.33643

Bennett, G., Diemer, M., Kerford, J., Probert, T. \& Wesi, T., 2016, 'Setswana (South African)', Journal of the International Phonetic Association 46(2), 235-246. https://doi.org/10.1017/\$0025100316000050

Census, 2011, Statistics South Africa, Pretoria, viewed 18 June 2019, from http:// www.statssa.gov.za/?page_id=3839.

Cleary, S., 2014, Communication: A hands-on approach, 2nd edn., Juta, Cape Town.

Cole, D.T., 1992, An introduction to Tswana grammar, 7th impression, Longman, London.

Creswell, J.W., 2014, Research design: Qualitative, quantitative, and mixed methods approaches, 4th edn., SAGE, London.

De Klerk, V., 1999, 'Black South African English: Where to from here?', World Englishes 18(3), 311-324. https://doi.org/10.1111/1467-971X.00146

Ditsele, T., 2014, 'Perceptions of Black South African languages: A survey of the attitudes of Setswana-speaking university students toward the first language', Doctoral thesis, Tshwane University of Technology, Pretoria.

Ditsele, T., 2016, 'Attitudes held by Setswana L1-speaking university students toward their L1: New variables', South African Journal of African Languages 36(1), 1-13. https://doi.org/10.1080/02572117.2016.1186887

Ditsele, T., 2017, 'Testing the impact of known variables on the attitudes held by Setswana L1-speaking university students toward their L1', Literator 38(1), 1-15. https://doi.org/10.4102/lit.v38i1.1301

Erasmus-Kritzinger, L.E., Bowler, A. \& Goliath, D., 2009, Effective communication Getting the message across in business, 12th impression, Van Schaik, Pretoria.

Grin, F., 1994, 'The economics of language: Match or mismatch?', International Political Science Review 15(1), 25-42. https://doi.org/10.1177/01925121940 1500103

Heugh, K., 2000, The case against bilingual and multilingual education in South Africa, viewed 21 March 2020, from http://www.praesa.org.za/wp-content/ uploads/2017/01/Paper6.pdf.

Mack, N., Woodsong, C., MacQueen, K.M., Guest, G. \& Namey, E., 2005, Qualitative research methods: A data collector's field guide, Family Health International, Durham.

MacMillan, C.M., 1998, The practice of language rights in Canada, University of Toronto Press, Toronto.

Magocha, K.K., 2010, 'Evaluation in business discourse', Doctoral thesis, North-West University, Mafikeng.

Mohlahlo, A.L., 2019, 'Implementing the official Language Act: A comparative study of selected national departments in South Africa', Master's dissertation, Tshwane University of Technology, Pretoria.

Neuliep, J.W., 2006, Intercultural communication: A contextual approach, 3rd edn., SAGE, Thousand Oaks, CA.

PanSALB, 2000, Language use and language interaction in South Africa: Summary report of the national sociolinguistic survey conducted by MarkData on behalf of PanSALB, PanSALB, Pretoria.

Peters, R.M. \& Brijal, P., 2011, 'The relationship between levels of education of entrepreneurs and their business success: A study of the province of KwaZuluNatal, South Africa', Industry and Higher Education 25(4), 265-275. https://doi. org/10.5367/ihe.2011.0048 
Phaahla, P., 2006a, 'Knowledge production in what language? The hegemonic use of English as a language of commerce and industry from a South African perspective',
in O.F. Arasanyin \& M. Pemberton (eds.), Selected Proceedings of the 36th Annual Conference on African Linguistics, Cascadilla Proceedings Project, pp. 142-154, Somerville, MA.

Phaahla, P., 2006b, 'The feasibility of Northern Sotho as a language of commerce and industry in the Limpopo and Gauteng province', Doctoral thesis, University of industry in the Limpopo and
Johannesburg, Johannesburg.

Phaahla, P., 2010, 'Multilingualism in a global village: What is the future of local language (e.g. Northern Sotho) in an increasingly globalised world?', South African Journal of
African Languages 30(1), 52-65. https://doi.org/10.1080/02572117.2010.10587335

Phaahla, P., 2015, 'Economics of languages: The interplay between language planning and policy, and language practice in South Africa', South African Journal of African
Languages 35(2), 181-188. https://doi.org/10.1080/02572117.2015.1113003
Ranamane, T.D., 2012, 'The contribution of the missionaries to the development of Setswana as a written language', South African Journal of African Languages 32(1), 27-33. https://doi.org/10.2989/SAJAL.2012.32.1.5.1128

Republic of South Africa, 1996, The Constitution of the Republic of South Africa (Act 108 of 1996), Government Printers, Pretoria.

Republic of South Africa, 2012, Use of Official Languages Act (No. 12 of 2012), Government Printers, Pretoria.

Republic of Zimbabwe, 2013, The Constitution of the Republic of Zimbabwe (Act 20 of 2013), Harare.

Wagner, V.K., Ditsele, T. \& Makgato, M.M., 2020, 'Influence of Sepitori on standard Setswana of its home language learners at three Tshwane townships', Literator 41(1), 1-7. https://doi.org/10.4102/lit.v41i1.1653

Appendices starts on the next page $\rightarrow$ 


\section{Appendix 1}

TABLE 1-A1: Customers' biographic details.

\begin{tabular}{|c|c|c|c|c|c|}
\hline Interviewee code & Sex & Setswana competence & Age group (years) & Highest qualification & Town \\
\hline CF1-CS1 & Female & L1 & $21-29$ & National Diploma & Krugersdorp \\
\hline CF2-CS1 & Female & L1 & $50-59$ & Below Grade 12 & Krugersdorp \\
\hline CF3-CS2 & Female & L2 & $18-20$ & Grade 12 & Krugersdorp \\
\hline CF4-CS3 & Female & L1 & $30-39$ & Grade 12 & Krugersdorp \\
\hline CF5-CS1 & Female & L1 & $40-49$ & Grade 12 & Randfontein \\
\hline CF6-CS2 & Female & L1 & $50-59$ & Below Grade 12 & Randfontein \\
\hline CF7-CS3 & Female & L1 & $50-59$ & National Diploma & Randfontein \\
\hline CF8-CS1 & Female & L2 & $21-29$ & Grade 12 & Randfontein \\
\hline CF9-CS2 & Female & L2 & $30-39$ & Grade 12 & Randfontein \\
\hline CF10-CS3 & Female & L2 & $30-39$ & Grade 12 & Carletonville \\
\hline CF11-CS3 & Female & L2 & $21-29$ & National Diploma & Carletonville \\
\hline CM1-CS2 & Male & L1 & $50-59$ & National Diploma & Krugersdorp \\
\hline $\mathrm{CM} 2-\mathrm{CS} 3$ & Male & L2 & $30-39$ & Below Grade 12 & Krugersdorp \\
\hline CM3-CS1 & Male & L2 & $21-29$ & National Diploma & Randfontein \\
\hline CM5-CS3 & Male & L1 & $21-29$ & Grade 12 & Randfontein \\
\hline CM6-CS1 & Male & L2 & $21-29$ & Grade 12 & Carletonville \\
\hline CM7-CS2 & Male & L2 & $21-29$ & Below Grade 12 & Carletonville \\
\hline
\end{tabular}

CF1, female customer number 1; CS1, clothing store catering for low-income earners; CM2, male customer number 2; CS3, clothing store catering for high-income earners.

\section{Appendix 2}

TABLE 1-A2: Salespersons' biographic details.

\begin{tabular}{|c|c|c|c|c|c|c|}
\hline Interviewee code & Sex & Setswana competence & Age group (in years) & Duration at the workplace & Job title & Town \\
\hline SF1-CS1 & Female & L2 & $30-39$ & 11 years & Salesperson (cell phones) & Krugersdorp \\
\hline SF2-CS2 & Female & L1 & $30-39$ & 11 years & Sales consultant (cosmetics) & Krugersdorp \\
\hline SF3-CS1 & Female & L2 & $30-39$ & 5 years & Salesperson (service centre) & Randfontein \\
\hline SF4-CS1 & Female & L2 & $21-29$ & 5 years & Salesperson & Randfontein \\
\hline SF5-CS3 & Female & L2 & $21-29$ & 4 years & Sales consultant & Randfontein \\
\hline SF6-CS1 & Female & L1 & $21-29$ & 2 years & Salesperson & Carletonville \\
\hline SF8-CS2 & Female & L2 & $30-39$ & 3 years & Salesperson (cell phones) & Carletonville \\
\hline SF9-CS2 & Female & L2 & $30-39$ & 10 years & Salesperson & Carletonville \\
\hline SF10-CS3 & Female & L2 & $21-29$ & 9 months & Sales consultant & Carletonville \\
\hline SF11-CS3 & Female & L1 & $40-49$ & 13 years & Salesperson & Carletonville \\
\hline SM1-CS1 & Male & L1 & $40-49$ & 29 years & Retail associate & Krugersdorp \\
\hline SM2-CS2 & Male & L2 & $21-29$ & 3 years & Sales consultant (customer service) & Krugersdorp \\
\hline SM3-CS3 & Male & L1 & $21-29$ & 1 year & Sales consultant & Krugersdorp \\
\hline SM5-CS2 & Male & L2 & $21-29$ & 3 years & Salesperson & Randfontein \\
\hline SM6-CS2 & Male & L2 & $21-29$ & 3 years & Salesperson & Randfontein \\
\hline SM7-CS3 & Male & L1 & $21-29$ & 7 months & Sales consultant & Randfontein \\
\hline
\end{tabular}

SF5, female salesperson number 5; CS3, clothing store catering for high-income earners; SM2, male salesperson number 2; CS2, clothing store catering for middle-income earners. 